\title{
Characteristics, determinants and cost implications of severe adverse drug reactions in the intensive coronary care unit of a hospital
}

\author{
Nitin S. Kunnoor, Anand R. Kanaki, Sharanabasappa Singanal*
}

Department of Pharmacology, M. R. Medical College and Hospital, Karnataka, India

Received: 05 October 2016 Accepted: 03 November 2016

\section{*Correspondence to:}

Dr. Sharanabasappa Singanal, Email: sharan2014@gmail.com

Copyright: () the author(s), publisher and licensee Medip Academy. This is an openaccess article distributed under the terms of the Creative Commons Attribution NonCommercial License, which permits unrestricted noncommercial use, distribution, and reproduction in any medium, provided the original work is properly cited.

\begin{abstract}
Background: The objective of the study was to determine the predictors, frequency, characteristics and incremental costs of severe Adverse Drug Reactions in the Intensive Coronary Care Unit (ICCU) of a hospital.

Methods: Two trained physicians prospectively reviewed case records of all inpatients admitted to ICCU over one year (July 2015 to June 2016) and identified ADRs. Each ADR was assessed for causality, severity, predictability and preventability. Determinants of severe ADRs were identified using multiple binary logistic regression analysis. Cost of severe ADR was estimated based on the corrected duration of excess hospital stay after adjusting for age, gender, comorbid conditions and number of drugs.

Results: Of 573 cases admitted during one year, 47 (8\%) patients had 56 severe ADRs. Streptokinase $(16.1 \%)$ was the commonest drug associated with severe ADRs. Arrhythmias (30.4\%) were the commonest severe ADR. Presence of arrhythmias (OR 4.54, 95\% CI 2.25-9.14), renal dysfunction (OR 2.27, 95\% CI 1.01-5.11) and poly-pharmacy (>10 drugs) (OR 1.13, 95\% CI 1.007- 1.254) were found to be the predictors for occurrence of severe ADRs. Majority of severe ADRs were found to be probable $30(53.6 \%) .46(82 \%)$ were predictable and $25(44.6 \%)$ probably preventable severe ADRs. Patients with severe ADRs had a longer duration of ICCU (0.8 extra day) and hospital stay (1.5 extra days) (adjusted analysis). The mean incremental cost incurred by patients in the severe ADR group was \$ 32 (INR 2170/-) per patient based on the corrected duration of hospital stay.

Conclusions: Severe ADRs in ICCU add considerably to treatment costs. Cardiac arrhythmias, renal dysfunction, and polypharmacy are important predictors of severe ADRs.
\end{abstract}

Keywords: Cost, Intensive care, ICCU, Severe ADRs

\section{INTRODUCTION}

Adverse Drug Reactions (ADRs) are the $5^{\text {th }}$ leading cause of death in hospitalised patients in the United States (US), and account for an alarming $7 \%$ of all hospital admissions in US and United kingdom (UK). ${ }^{1,2}$ The debilitating and lethal consequences of severe ADRs are a major problem in modern day practice. In US, there are over 2 million severe reactions attributed to drugs, claiming 100,000 -218,000 lives annually costing over \$ 100 billion dollars each year. ${ }^{3,4}$ Wester $\mathrm{K}$ et al reported, fatal ADRs to be the seventh common cause of death in Sweden. ${ }^{5}$ ADRs have a major impact on public health by imposing a considerable financial burden on society and the already stretched healthcare systems.
In India, the scenario is not different. Nearly $4 \%$ of patients presenting to emergency department had ADRs. ADRs as cause of admissions to hospital amounted to $7 \%$. The estimated cost per patient due to hospitalization was \$ 92 (INR 6197/-). ${ }^{6}$

A study among CCU patients has shown that the ADR rate is as high as $24 \%$ with severe ADRs accounting $22 \%$ of the total. Of the severe ADRs $7 \%$ were potentially preventable.

Currently, studies evaluating the nature of ADRs among ICCU patients are limited. Severe ADRs which causes extra burden to patients is hardly considered while evaluating the total health care expenses. The objective of the present study was to assess the frequency, characteristics and predictors of severe ADRs and to 
assess the cost implications of severe ADRs in the ICCU of a hospital.

\section{METHODS}

\section{Study design and setting}

This is a prospective observational study conducted in the ICCU of M R Medical College and Hospital, Karnataka, India. All ADRs were independently assessed by two physicians (investigators) who are also expert in pharmacovigilance.

\section{Data collection}

All 573 consecutive patients admitted to the ICCU were prospectively revived for ADRs from $1^{\text {st }}$ July 2015 to $30^{\text {th }}$ June, 2016. Two physicians independently reviewed and collected relevant data from inpatient hospital charts. Individual inpatient prescriptions, the doctors and nurses progress notes were carefully evaluated for severe ADRs and possibly causative medications. We collected data on patient demographics, the existence of other co-morbid conditions, investigations performed, treatments prescribed, length of stay in ICCU and hospital and data on observed severe ADRs (organ system involved, suspected drug, reaction time, management and outcome). The Institutional Ethics Committee approved the study.

\section{Data evaluation and analysis}

We detected ADRs based on the WHO definition, i.e.; a response to a medicine which is noxious and unintended, and which occurs at doses normally used in man for the prophylaxis, diagnosis, or therapy of disease or for the modification of a physiological function. ${ }^{8}$

The severity of the ADRs was assessed using Hartwig and Siegel scale as mild, moderate and severe ADRs. ${ }^{9}$ A severe adverse reaction is any untoward medical occurrence that at any dose results in death, is lifethreatening, requires inpatient hospitalization or prolongation of existing hospitalization, results in persistent or significant disability/incapacity, or a congenital anomaly/birth defect.

The aim of the causality assessment is to establish a level of probability regarding the suspicion that a certain drug may be responsible for an adverse reaction. Naranjo's algorithm was used to assess the causality of ADRs. ${ }^{10}$ Schumock and Thornton scale was used to assess preventability. ${ }^{11}$ The predictability of the severe ADRs (predictable or non-predictable) was also assessed.

Renal dysfunction was defined based on the estimated creatinine clearance $(\mathrm{ml} / \mathrm{min})$ values calculated using the Cockroft-Gault equation. Values of $120 \mathrm{ml} / \mathrm{min} / 1.73 \mathrm{~m}^{2}$ for men and $100 \mathrm{ml} / \mathrm{min} / 1.73 \mathrm{~m}^{2}$ for women were considered normal. Major bleeding, acute renal failure (ARF) was considered based on physicians report.

\section{Severe ADRs related excess stay and cost in hospital}

a) The unadjusted number of excess hospital days, i.e. difference between mean duration of hospital stay of patients having had an severe ADR in the hospital and the mean duration of hospital stay for patients without any ADR. ${ }^{12}$

b) The corrected number of excess hospital days, i.e. differences between mean duration of hospital stay of patients with severe ADRs in hospital and the mean duration of hospital stay for patients without ADR, after correction of duration of hospital stay for age, gender, number of co-morbid conditions and number of drugs (multivariate regression analysis). ${ }^{13}$

c) Additional cost of management of severe ADR was estimated by multiplying total corrected number of excess hospital days by the reference daily hospital cost, based on the hospital charges for the year 2015-2016.

Two investigators (physicians) assessed independently each ADR for causality, severity, predictability and preventability and the level of agreement determined. Disagreements were sorted out by consensus between two reviewing investigators.

\section{Statistical analysis}

Descriptive analysis was used to study the characteristics of severe ADRs. Continuous parametric variables are reported as percentages as mean \pm standard deviation. Continuous non-parametric variables are reported as median and interquartile ranges (IQR; 25-75\%). Chisquare and $t$ tests are used appropriately to compare between the severe ADR and non-ADR groups. A statistical significance level was set at 0.05 .

The predictors for developing severe ADRs in the ICCU were identified using multivariate logistic regression analysis. Variables that displayed a tendency towards a significant association with severe ADRs (significance level of $<0.2$ on the univariate analysis) were included in the multivariate binary logistic regression analysis. SPSS version 18.0 (SPSS, Chicago, IL) used for statistical analysis.

\section{RESULTS}

\section{Baseline characteristics of patients}

During the study period ( $1^{\text {st }}$ July 2015 to $30^{\text {th }}$ June, 2016) a total of 573 consecutive patients were admitted and there case charts were reviewed. A total of 177 ADRs were noted of which 47 patients had $56(31.6 \%)$ severe ADRs as per the Hartwig and Siegel severity scale. The 
mean age of the patients in the severe ADR and nonADR groups was $59.8( \pm 15.4)$ years and $56.7( \pm 15.1)$ years, respectively $(\mathrm{p}=0.05)$. In our study, patients with severe ADRs, 34 (72.3\%) were males and $13(27.7 \%)$ were females. $38(6.4 \%)$ patients had one severe ADR and $9(1.5 \%)$ had two severe ADRs.

Table 1: Baseline characteristics of patients with severe ADRs and patients without any ADR.

\begin{tabular}{|llll|}
\hline Characteristic & $\begin{array}{l}\text { Severe } \\
\text { ADR } \\
\text { group } \\
\mathbf{N}=47\end{array}$ & $\begin{array}{l}\text { Non- } \\
\text { ADR } \\
\text { group } \\
\mathbf{N}=443\end{array}$ & P value \\
\hline Age, Mean \pm ( SD) & $\begin{array}{l}59.8 \\
(15.4)\end{array}$ & $56.7(15.1)$ & 0.05 \\
\hline $\begin{array}{l}\text { Gender n (\%) } \\
\text { Male } \\
\text { Female }\end{array}$ & $34(72.3)$ & $291(65.7)$ & 0.514 \\
\hline $\begin{array}{l}\text { Co-morbidities n }(\%) \\
\text { <3 } \\
>3\end{array}$ & $13(27.7)$ & $147(33.2)$ & \\
\hline $\begin{array}{l}\text { Duration of ICCU } \\
\text { stay, Median } \\
(\text { IQR; 25-75\%) }\end{array}$ & $35(74.5)$ & $274(61.9)$ & 0.20 \\
\hline $\begin{array}{l}\text { Duration of hospital } \\
\text { stay, Median } \\
\text { (IQR; 25-75\%) }\end{array}$ & $9(8,11)$ & $6(4,7)$ & $<0.0001$ \\
\hline $\begin{array}{l}\text { Number of } \\
\text { medications per } \\
\text { patient, Mean }( \pm \text { SD) }\end{array}$ & $11(2.5)$ & $9.3(3.0)$ & $<0.0001$ \\
\hline
\end{tabular}

Data are given as the number (n) of patients with the percentage in parentheses, or as the mean \pm standard deviation (SD) or as median with inter-quartile range in parentheses. $\mathrm{P}<0.05$ considered significant.

Patients with severe ADRs had a significantly longer duration of ICCU stay $[3(2,4)$ vs $2(2,4)$ days; $\mathrm{p}<0.0001]$ and longer total hospital stay $[9(8,11)$ vs 6 $(4,7)$ days; ( $<<0.0001)$; (unadjusted analysis)]. Patients with severe ADRs also received more medications than patients in the non-ADR group $[11 \pm 2.5$ vs $9.3 \pm 3.04$; $(\mathrm{p}<0.0001)$; unadjusted analysis] (Table 1).

Among patients who had severe ADRs, diagnosis of myocardial infarction [26 (55.3\%)] and congestive cardiac failure $[8(17 \%)]$ constituted the most common cause of admissions to the ICCU. Arrhythmias [severe ADR group, 19 (40.4\%) vs non-ADR group, 69 (15.6\%); $\mathrm{p}<0.0001]$ and renal dysfunction $[16 \quad(34 \%)$ vs 69 $(15.6 \%) ; \mathrm{p}=0.001]$ were significantly more common in severe ADRs group. Top five co-morbidities associated with severe ADRs are given in Table 2.

\section{Characteristics of severe ADRs}

Of 56 severe ADRs, 53.6\% rated as probable upon causality assessment, $82.1 \%$ being predictable ADRs, $44.6 \%$ of the severe ADRs were identified as probably preventable using the Schumock and Thornton scale (Table 3).
Table 2: Top five co-morbidities in patients with severe ADRs.

\begin{tabular}{|c|c|c|c|}
\hline $\begin{array}{l}\text { Co-morbid } \\
\text { condition }\end{array}$ & $\begin{array}{l}\text { Severe } \\
\text { ADR } \\
\text { Group } \\
\mathbf{N}=47 \\
\text { n }(\%)\end{array}$ & $\begin{array}{l}\text { Non ADR } \\
\text { Group } \\
\text { N= 443 } \\
\text { n (\%) }\end{array}$ & $\begin{array}{l}\mathbf{P} \\
\text { value }\end{array}$ \\
\hline $\begin{array}{l}\text { Myocardial } \\
\text { infraction }\end{array}$ & $26(55.3)$ & $188(42.4)$ & 0.09 \\
\hline Hypertension & $26(55.3)$ & $255(57.6)$ & 0.76 \\
\hline Arrhythmias & $19(40.4)$ & $69(15.6)$ & $<0.0001$ \\
\hline $\begin{array}{l}\text { Diabetes } \\
\text { mellitus }\end{array}$ & $16(34.0)$ & 198(44.7) & 0.16 \\
\hline $\begin{array}{l}\text { Renal } \\
\text { dysfunction }\end{array}$ & $16(34.0)$ & 69 (15.6) & 0.001 \\
\hline
\end{tabular}

$\mathrm{P}<0.05$ considered significant.

Table 3: Causality, predictability and preventability of severe ADRs.

\begin{tabular}{|lll|}
\hline $\begin{array}{l}\text { Classification of } \\
\text { ADRs }\end{array}$ & Type & $\begin{array}{l}\text { Severe } \\
\text { ADRs, N= } \\
\text { 56 }\end{array}$ \\
\hline Causality & Possible & $26(46.4)$ \\
\cline { 2 - 3 } & Probable & $30(53.6)$ \\
\hline Predictability & Predictable & $47(82.1)$ \\
\cline { 2 - 3 } & Not predictable & $9(16.0)$ \\
\hline Preventability & $\begin{array}{l}\text { Probably } \\
\text { preventable }\end{array}$ & $25(44.6)$ \\
\cline { 2 - 3 } & Not preventable & $31(55.4)$ \\
\hline
\end{tabular}

Table 4: Clinical spectrum of top five severe ADRs occurring in the ICCU.

\begin{tabular}{|ll|}
\hline Severe ADR & $\mathbf{N}=\mathbf{5 6} \mathbf{n}(\boldsymbol{\%})$ \\
\hline Cardiac arrhythmias & $17(30.35)$ \\
\hline Major bleeding & $7(12.5)$ \\
\hline Acute Renal Failure & $5(8.9)$ \\
\hline Hypoglycaemia & $4(7.1)$ \\
\hline Hypotension & $3(5.3)$ \\
\hline
\end{tabular}

\section{Characteristics of severe ADRs by organ system affected and drugs implicated}

The ADRs involving the cardiovascular system were the most frequent $(39.3 \%)$, with cardiac arrhythmias $(30.35 \%)$ being the most common severe ADR. Haematological ADRs in form of bleeding (12.5\%) and ADRs involving renal system $(8.9 \%)$ were the other most frequently involved organ systems (Table 4 ).

Streptokinase caused the most number of severe ADRs 9 (16.1\%) - tachyarrhythmia (4), type 1 hypersensitivity reactions (3), embolic stroke (1) and major bleeding (1). Ramipril induced acute renal failure (5) and metoprolol induced bradycardia (4), digoxin induced 
tachyarrhythmia were the other common drugs associated with severe ADRs (Table 5).

Imipenem induced seizures (1), phenytoin induced purple glove syndrome (PGS) (1), terbutaline containing cough syrup induced tachyarrhythmia (1), cyclosporine induced hypertensive crisis (1), danazol induced hyponatremia (1) were some of the infrequently reported severe ADRs identified in the study (Table 5).

Table 5: Characteristics of severe ADRs by organ system affected and drugs implicated.

\begin{tabular}{|c|c|c|}
\hline Organ system and ADR & Drugs implicated & $\begin{array}{l}N=56 \\
n(\%)\end{array}$ \\
\hline $\begin{array}{l}\text { Cardiovascular system } \\
\text { Arrhythmias, Tachyarrhythmias } \\
\text { Bradycardia/complete heart block } \\
\text { Severe hypotension } \\
\text { Hypertensive crisis } \\
\text { Purple glove syndrome } \\
\text { Myocardial Hypertrophy and Infarction }\end{array}$ & $\begin{array}{l}\text { Digoxin (6), epinephrine (1), streptokinase (4) } \\
\text { (reperfusion arrhythmias), terbutaline (1) (cough syrup), } \\
\text { salbutamol (1) } \\
\text { Metoprolol (4) } \\
\text { Nitroglycerine (2) } \\
\text { Cyclosporine (1) } \\
\text { Phenytoin (1) } \\
\text { Oxandrolone (1) }\end{array}$ & $22(39.3)$ \\
\hline $\begin{array}{l}\text { Hematological } \\
\text { Major bleeding } \\
\text { Leukopenia }\end{array}$ & $\begin{array}{l}\text { Streptokinase (1), warfarin (1), eptifibatide (1), heparin (4) } \\
\text { Ceftriaxone (1) }\end{array}$ & $8(14.3)$ \\
\hline $\begin{array}{l}\text { Endocrine and metabolic } \\
\text { Hypoglycemia } \\
\text { Hypoglycemia with metabolic acidosis } \\
\text { Diabetes mellitus } \\
\text { Hypothyroidism }\end{array}$ & $\begin{array}{l}\text { Insulin (1), Glibenclamide (1) } \\
\text { Glibenclamide metformin combination (1) } \\
\text { Cyclosporine (1), prednisolone chronic therapy (1) } \\
\text { Amiodarone (1) }\end{array}$ & $6(10.7)$ \\
\hline $\begin{array}{l}\text { Renal system } \\
\text { Acute renal failure }\end{array}$ & 201 & $5(8.9)$ \\
\hline $\begin{array}{l}\text { Electrolyte imbalance } \\
\text { Hyperkalemia } \\
\text { Hyponatremia } \\
\text { Hypokalemia }\end{array}$ & $\begin{array}{l}\text { Spironolactone (1) } \\
\text { Danazol (1) } \\
\text { Furosemide (2) }\end{array}$ & $4(7.1)$ \\
\hline $\begin{array}{l}\text { CNS } \\
\text { Seizures } \\
\text { Embolic stroke }\end{array}$ & $\begin{array}{l}\text { Imipenem (1) } \\
\text { Streptokinase (1) }\end{array}$ & $2(3.6)$ \\
\hline $\begin{array}{l}\text { Hypersensitivity } \\
\text { Type I hypersensitivity reactions }\end{array}$ & Streptokinase (3) & $3(5.3)$ \\
\hline $\begin{array}{l}\text { Gastrointestinal tract } \\
\text { Erosive gastritis with upper GI bleed }\end{array}$ & Aspirin (2) & $2(3.6)$ \\
\hline Others & & $4(7.1)$ \\
\hline
\end{tabular}

\section{Predictors for occurrence of severe ADRs in the ICCU}

The multivariate logistic regression analysis showed that patients with cardiac arrhythmias (OR 4.54, 95\% CI 2.25-9.14), renal dysfunction [OR 2.27, 95\% CI 1.015.11) and polypharmacy with $>10$ prescribed drugs in the ICCU (OR 1.12, 95\% CI 1.007- 1.254) had a higher risk of experiencing severe ADRs in the Intensive coronary care unit (Table 6).

\section{Calculation of cost of ADRs}

Patients with severe ADR had 0.9 extra days (3.8 days, severe ADR group Vs 2.9 days, non-ADR group) in ICCU and an overall additional 2.8 days of total hospital stay (10.4 days Vs 7.6 days) compared to the non ADR group in the unadjusted analysis.

This was adjusted for age, gender, number of comorbidities and number of medications by multivariate regression analysis to obtain the corrected number of excess hospital stay. The corrected excess hospital stay was 3.2 Vs 2.4 days of ICCU stay and 7.6 Vs 6.1 days of total hospital stay, for the severe ADRs and non- ADR groups respectively. 
The mean incremental cost incurred by the patients in severe ADR group was \$ 32 (INR 2170/-) per patient based on the corrected duration of excess hospital days (Table 7).

Table 6: Risk factors for the development of severe ADRs in the ICCU.

\begin{tabular}{|c|c|c|c|c|}
\hline Variables & $\begin{array}{l}\text { B } \\
\text { coefficient }\end{array}$ & $\begin{array}{l}P \\
\text { value }\end{array}$ & $\begin{array}{l}\text { Odds } \\
\text { ratio }\end{array}$ & $95 \% \mathrm{CI}$ \\
\hline Age & 0.003 & 0.833 & 1.01 & $\begin{array}{l}0.977- \\
1.029\end{array}$ \\
\hline Gender & 0.366 & 0.342 & 1.44 & $\begin{array}{l}0.678- \\
3.066 \\
\end{array}$ \\
\hline Arrhythmias & 1.512 & $\begin{array}{l}< \\
0.0001\end{array}$ & 4.54 & $\begin{array}{l}2.252- \\
9.144\end{array}$ \\
\hline $\begin{array}{l}\text { Renal } \\
\text { dysfunction }\end{array}$ & 0.821 & 0.047 & 2.27 & $\begin{array}{l}1.011- \\
5.114 \\
\end{array}$ \\
\hline $\begin{array}{l}\text { Number of } \\
\text { drugs } \\
\text { prescribed }\end{array}$ & 0.117 & 0.037 & 1.12 & $\begin{array}{l}1.007- \\
1.254\end{array}$ \\
\hline $\begin{array}{l}\text { Number of } \\
\text { co- } \\
\text { morbidities }\end{array}$ & -0.094 & 0.513 & 0.91 & $\begin{array}{l}0.686- \\
1.207\end{array}$ \\
\hline
\end{tabular}

Table 7: Comparison of duration of and costs incurred in ICCU stay and net hospital stay between severe ADR and non-ADR groups.

\begin{tabular}{|llll|}
\hline Days spent & Estimates & $\begin{array}{l}\text { Severe } \\
\text { ADR } \\
\text { group (n } \\
\text { = 47) }\end{array}$ & $\begin{array}{l}\text { Non } \\
\text { ADR } \\
\text { group } \\
\text { (n= 443) }\end{array}$ \\
\hline ICCU & $\begin{array}{l}\text { Unadjusted } \\
\text { estimate }\end{array}$ & 3.8 & 2.9 \\
\cline { 2 - 4 } & $\begin{array}{l}\text { Adjusted } \\
\text { estimate }\end{array}$ & 3.2 & 2.4 \\
\hline \multirow{2}{*}{$\begin{array}{l}\text { Total hospital } \\
\text { stay }\end{array}$} & $\begin{array}{l}\text { Unadjusted } \\
\text { estimate }\end{array}$ & 10.4 & 7.6 \\
\cline { 2 - 4 } & $\begin{array}{l}\text { Adjusted } \\
\text { estimate }\end{array}$ & 7.6 & 6.1 \\
\hline $\begin{array}{l}\text { Cost per } \\
\text { patient (INR) }\end{array}$ & Unadjusted & 8617 & 6592 \\
\hline $\begin{array}{l}\text { Cost incurred } \\
\text { in the ICCU }\end{array}$ & Adjusted & 7290 & 5400 \\
\hline $\begin{array}{l}\text { Total } \\
\text { expenses in } \\
\text { hospital } \\
\text { (expenses } \\
\text { only of excess } \\
\text { hospital stay) }\end{array}$ & Unadjusted & 11257 & 8456 \\
\cline { 2 - 4 } & Adjusted & 9050 & 6880 \\
\hline Estmas adjusted & & \\
\hline
\end{tabular}

Estimates adjusted for age, gender, number of co-morbidities and number of medications prescribed.

\section{DISCUSION}

In our study, a total of 56 severe ADRs (29\%) were identified in 47 patients. Severe ADRs pertaining to the cardiovascular system (32\%) were most commonly identified with cardiac arrhythmias (25\%) being the most frequent severe ADR in the ICCU. Streptokinase (16\%) was the most common drug involved in severe ADRs in ICCU. 54\% were probably associated with the suspected drug on causality assessment, $82 \%$ were predictable and $45 \%$ were potentially preventable severe ADRs.

A prospective study evaluating the risk of severe ADRs in 667 ICCU patients demonstrated a rate of $22.2 \%$ of severe ADRs and $6.9 \%$ of the severe ADRs rated preventable. The highest ADR rates were observed with streptokinase $(59.3 \%){ }^{14}$ Our study, evaluated severe ADRs classified using the Hartwig and Siegel severity assessment scale. We demonstrate a comparable rate of occurrence, but with a higher rate $(44.6 \%)$ of preventability of severe ADRs.

Patients with severe ADRs were older than non-ADR group (59.8 vs 56.7 , mean age in years, $\mathrm{P}=0.05$ ), took more drugs than patients without any ADR $(11+2.5 \mathrm{Vs}$ $9.3+3, \mathrm{P}<0.0001)$. A higher proportion of males had severe ADRs than females. A prospective study by Moore et al. ${ }^{15}$ found that patients with severe ADRs were older, took more medications than patients with non ADR group but were more common in females (66.2\%). These results demonstrate that severe ADRs constitute a significant problem. $82 \%$ of the reported severe ADRs were predictable and dose related. Such ADRs could have been identified and perhaps avoided, resulting in considerable saving of health care resources and minimising the suffering to the patient. ADRs adversely affect the quality of life and add to the direct and indirect costs of already burdened healthcare systems, thereby affecting the society at large. ${ }^{16,17}$

Presence of renal dysfunction, arrhythmias and polypharmacy (>10 drugs) in patients were identified as the predictors for occurrence of severe ADRs in ICCU. As the proportion of patients having arrhythmias and renal dysfunction in the ICCU is relatively high, the proportion of ADRs such as tachyarrhythmias by digoxin, streptokinase and acute renal failure induced by angiotensin-converting enzyme inhibitors was also high. Type-A predictable reactions are more in patients with renal dysfunction taking drugs which are excreted through kidneys. ${ }^{18}$ Risk of having an ADR increases exponentially as the number of medicines being taken by the patient increases. ${ }^{19}$ These ADRs constitute potentially preventable ADRs by better dose titrations and number of drugs administered to patients.

Our study also observed some rare but important severe ADRs like phenytoin induced PGS, cyclosporine induced hypertensive crisis, danazol induced hyponatremia. (Table 5) Previous studies have reported that elderly patients and individuals receiving large, multiple doses of intravenous phenytoin are particularly at risk of having PGS. $^{20}$ 
Cyclosporin A, which is a nephrotoxic agent, has been a mainstay antirejection drug in heart, kidney and lung transplant programmes for about a decade. Patients with pre-existing hypertension may rapidly develop severe hypertension and encephalopathy. This is because, the small arteries of the kidney, including the afferent arteriole, undergo pathologic changes that alter renal auto regulation, showing signs of endothelial dysfunction and impaired vasodilation. This leads to vasoconstriction, reduced glomerular filtration and sodium retention. ${ }^{21}$ Because of the small number of cases with danazole induced hyponatremia, no firm conclusions regarding common etiologic factors are present. ${ }^{22}$

Patients with severe ADRs had a significantly longer duration of ICCU stay $(\mathrm{p}<0.0001)$ and total hospital stay ( $\mathrm{p}<0.0001)$ (unadjusted analysis, Table 1). Comparing with previous study by Moore et al., ${ }^{23}$ the mean duration of stay in hospital was longer in severe ADR patients than non ADR patients [19.2 (3-36) vs 10.7 (1-50), P $<0.05]$

In our study, the cost of management of severe ADRs amounted to $\$ 32$ (as per 2015 exchange rates, INR 2170/-) per patient in ICCU based on the corrected duration of excess hospital stay. In view of the growing burden of cardiovascular disease, reaching epidemic proportions in the country, ${ }^{24}$ the higher incidence of occurrence of severe ADRs calls for immediate measures for prevention.

In our study, $45 \%$ of the severe ADRs were evaluated as probably preventable and cardiovascular ADRs were the most common severe ADRs. This underlines the urgent need for preventive measures to limit the economic burden imposed by severe ADRs. It is necessary to implement preventive programmes, with different strategies consisting of educational programmes of health care personnel; identifying risk groups; implementing rational drug prescribing practices; clinical and laboratory monitoring for severe ADRs. ${ }^{25}$

This is among very few studies done in South Asia region which demonstrates that severe ADRs add considerably to the overall treatment cost. This prospective study documented the ADRs from single ICCU setting. The costing of severe ADRs in this study was based only on the excess duration of total hospital stay secondary to the occurrence of severe ADRs during the ICCU stay. This does not include the cost of drugs used in treatment, but only the bed charges of the extended stay.

In conclusion, severe ADRs constitute a significant proportion of patients admitted the Intensive Coronary Care Unit of hospitals. Presence of renal dysfunction, cardiac arrhythmias and polypharmacy are the important predictors for occurrence of severe ADRs. They impose a significant burden to patient management not only complicating the treatment outcomes, but also add to the cost of management. Majority of the severe ADRs can be prevented if proper preventive measures are taken.

\section{ACKNOWLEDGEMENT}

The authors sincerely and gratefully thank Mrs. Priyanka $\mathrm{K}$, Research Assistant, and acknowledge the support of doctors, nursing staff of ICCU.

Funding: No funding sources

Conflict of interest: None declared

Ethical approval: The study was approved by the Institutional Ethics Committee

\section{REFERENCES}

1. Lazarou J, Pomeranz BH, Corey PN. Incidence of adverse drug reactions in hospitalized patients: a meta-analysis of prospective studies. JAMA. 1998;279(15):1200-5.

2. Pirmohamed M, James S, Meakin S, Green C, Scott AK, Walley TJ et al. Adverse drug reactions as cause of admission to hospital: prospective analysis of 18 820 patients. BMJ. 2004;329(7456):15-9.

3. Ernst FR, Grizzle AJ. Drug-related morbidity and mortality: updating the cost-of-illness model. J Am Pharm Assoc (Wash). 2001;41(2):192-9.

4. White TJ, Arakelian A, Rho JP. Counting the costs of drug-related adverse events. Pharmacoeconomics. 1999; 15(5):445-58.

5. Wester K, Jonsson AK, Spigset O, Druid H, Hagg S. Incidence of fatal adverse drug reactions: a population based study. $\mathrm{Br} \mathrm{J}$ Clin Pharmacol. 2008;65(4):573-9.

6. Patel KJ, Kedia MS, Bajpai D, Mehta SS, Kshirsagar NA, Gogtay NJ. Evaluation of the prevalence and economic burden of adverse drug reactions presenting to the medical emergency department of a tertiary referral centre: a prospective study. BMC Clin Pharmacol. 2007; 7:8.

7. Mohebbi N, Shalviri G, Salarifar M, Salamzadeh J, Gholami K. Adverse drug reactions induced by cardiovascular drugs in cardiovascular care unit patients. Pharmacoepidemiol Drug Saf. 2010;19(9):889-94.

8. Lindquist $M$. The need for definitions in pharmacovigilance. Drug Saf. 2007;30(10):825-30.

9. Hartwig SC, Siegel J, Schneider PJ. Preventability and severity assessment in reporting adverse drug reactions. Am J Hosp Pharm. 1992;49(9):2229-32.

10. Naranjo CA, Busto U, Sellers EM, Sandor P, Ruiz I, Roberts EA, et al. A method for estimating the probability of adverse drug reactions. Clin Pharmacol Ther. 1981;30(2):239-45.

11. Schumock GT, Thornton JP. Focusing on the preventability of adverse drug reactions. Hosp Pharm. 1992;27(6):538.

12. Moore N, Lecointre D, Noblet C, Mabille M. Frequency and cost of serious adverse drug reactions 
in a department of general medicine. $\mathrm{Br} \mathrm{J}$ Clin Pharmacol. 1998;45(3):301-8.

13. Hallas J, Harvald B, Gram LF, Grodum E, Brøsen K, Haghfelt T, et al. Drug related hospital admissions: the role of definitions and intensity of data collection, and the possibility of prevention. J Intern Med. 1990;228:83-90.

14. Mohebbi N, Shalviri G, Salarifar M, Salamzadeh J, Gholami K. Adverse drug reactions induced by cardiovascular drugs in cardiovascular care unit patients. Pharmacoepidemiol Drug Saf. 2010;19(9):889-94.

15. Moore N, Lecointre D, Noblet C, Mabille M. Frequency and cost of serious adverse drug reactions in a department of general medicine. $\mathrm{Br} \mathrm{J}$ Clin Pharmacol. 1998;45(3):301-8.

16. Gautier S, Bachelet H, Bordet R, Caron J. The cost of adverse drug reactions. Expert Opin Pharmacother. 2003;4(3):319-26.

17. Janaje Munasinghe TM, Singer DR. Costs and prevention of adverse drug reactions. Eur $\mathbf{J}$ Intern Med. 2001;12(5):403-5.

18. Davies EC, Green CF, Mottram DR, Pirmohamed M. Adverse drug reactions in hospitals: a narrative review. Curr Drug Saf. 2007;2(1):79-87.
19. Routledge PA, O'Mahony MS, Woodhouse KW. Adverse drug reactions in elderly patients. Br J Clin Pharmacol. 2004;57(2):121-6.

20. O'Brien TJ, Cascino GD, So EL, Hanna DR. Incidence and clinical consequence of the purple glove syndrome in patients receiving intravenous phenytoin. Neurology. 1998;51(4):1034-9.

21. Aggarwal M, Khan IA. Hypertensive crisis: hypertensive emergencies and urgencies. Cardiol Clin. 2006;24(1):135-46.

22. Letchumanan P, Thumboo J. Danazol in the treatment of systemic lupus erythematosus: a qualitative systematic review. Semin Arthritis Rheum. 2011;40(4):298-306.

23. Moore N, Lecointre D, Noblet C, Mabille M. Frequency and cost of serious adverse drug reactions in a department of general medicine. $\mathrm{Br} \mathbf{J}$ Clin Pharmacol. 1998;45(3):301-8.

24. Gersh BJ, Sliwa K, Mayosi BM, Yusuf S. Novel therapeutic concepts: the epidemic of cardiovascular disease in the developing world: global implications. Eur Heart J. 2010;31(6):642-8.

25. Gautier S, Bachelet H, Bordet R, Caron J. The cost of adverse drug reactions. Expert Opin Pharmacother. 2003;4(3):319-26.

Cite this article as: Kunnoor NS, Kanaki AR, Singanal S. Characteristics, determinants and cost implications of severe adverse drug reactions in the intensive coronary care unit of a hospital. Int J Basic Clin Pharmacol 2016;5:2657-63. 